\title{
Accounting Record Keeping Practices in Small and Medium Sized Enterprise's (SME's) in Sri Lanka
}

\author{
M. W. Madurapperuma ${ }^{1}$, P. M. C. Thilakerathne ${ }^{1}$, I. N. Manawadu ${ }^{2}$ \\ ${ }^{1}$ Department of Accountancy, Faculty of Commerce and Management Studies, University of Kelaniya, Kelaniya, Sri Lanka \\ ${ }^{2}$ Department of Interdisciplinary Studies, University of Moratuwa, Moratuwa, Sri Lanka
}

Email address:

wasanthi@kln.ac.lk (M. W. Madurapperuma), lal@kln.ac.lk (P. M. C. Thilakerathne), imanawadu@uom.lk (I. N. Manawadu)

\section{To cite this article:}

M. W. Madurapperuma, P. M. C. Thilakerathne, I. N. Manawadu. Accounting Record Keeping Practices in Small and Medium Sized Enterprise's (SME's) in Sri Lanka. Journal of Finance and Accounting. Vol. 4, No. 4, 2016, pp. 188-193. doi: 10.11648/j.jfa.20160404.14

Received: April 12, 2016; Accepted: May 6, 2016; Published: June 14, 2016

\begin{abstract}
Small and Medium Enterprises (SMEs) play vital role in many countries including Sri Lanka, because of its role for the country's economic growth. This study discovers the level of awareness towards the importance of Accounting Record Keeping Practices and its information usage in the business. The research design is based on a survey methodology using a sample of systematically selected SMEs in Gampaha District in Sri Lanka. The target population comprised of 100 SMEs operating retail shops, manufacturing firms and supplier's of various services in Gampaha district in Sri Lanka. It was concluded that the most of the SMEs do not keep complete accounting records because lack of accounting knowledge and the cost of hiring professional accountants. As a result, there is an inefficient use of accounting information to support financial performance measurement by SMEs. This made it difficult for the entrepreneurs to calculate their business profit efficiently. Lack of keeping of accurate records was highly blamed on the lack of skills in this field by the owners or managers. The study further revealed that the owners and managers of SMEs were highly willing to learn more about how to keep accurate records of their business transactions. The results of the study also revealed that majority of the SMEs encounter problems of lack of accounting knowledge. This study recommended that that the responsible authorities should come up with an effective programme for training for SMEs entrepreneurs.
\end{abstract}

Keywords: Accounting Practices, Accounting Information, Record Keeping, Small and Medium Enterprises (SME), Sri Lanka

\section{Introduction}

Small and Medium-sized Entities (SMEs) play important roles in the economic growth and sustainable development of every nation, (Moore WC, Petty JW, Palich CH, Longernecker JG., 2008). The government of Sri Lanka has identified entrepreneurship development as a major policy thrust to achieve economic development. The main reason of this concern is the growing need for entrepreneurs who accelerate economic development through generating new ideas and converting them into profitable ventures (Tucker, 2000), The Small Medium Enterprise (SME) sector has been identified as an significant strategic sector in the overall policy objectives of the Government of Sri Lanka (GOSL) and it is seen as a driver of change for wide-ranging economic growth, regional development, employment generation and poverty reduction. SME sector is envisaged to contribute to transform lagging regions into emerging regions of prosperity.

As shown in Figure 1, the rate of educated unemployment remains proportionally higher than the rate for less-educated workers in Sri Lanka. Today Sri Lankan government is facing a critical issue of providing employment opportunities for GCE A/L \& above. The development and growth of SMEs in Sri Lanka provides a solution to this problem. The Government of Sri Lanka recognizes SMEs as the backbone of the economy, as it accounts for more than $75 \%$ of the total number of enterprises, provides $45 \%$ of the employment and contributes to $52 \%$ of the Gross Domestic Production (GDP). SMEs promote broad based equitable development and provide more opportunity for Women and Youth participation in the economic development of the country. 


\section{Unemployemnt rate} (\%) by Level of Education, 2015

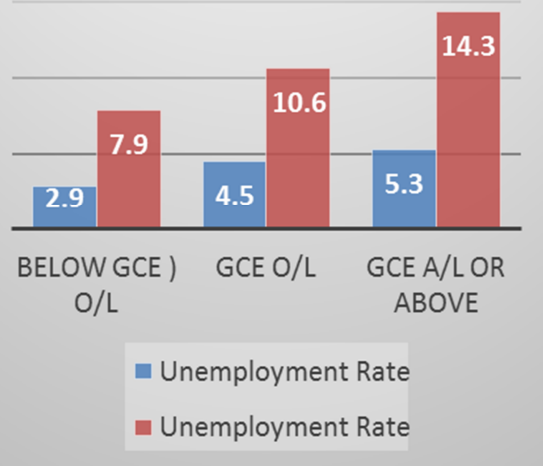

Source: Central Bank of Sri Lanka Report 2015

Figure 1. Unemployment rate by level of Education.

To upgrade and strengthen this sector it is important to have a government led intervention and support mechanism to meet the expectations of the country. SME Policy Framework aims to promote high potential, promising SMEs and improve business environment to allow them to realize their full potentials in today's globalized economy. Given the nature of this sector, there are many challenges the SMEs are facing. It has been recognized that appropriate accounting information is important for successful management of any business entity, whether large or small.

Accounting systems provide a source of information to owners and managers of SMEs operating in any industry for use in the measurement of financial performance. The importance of financial performance measurement to any business entity, big or small, cannot be over-emphasized. In any sense, profit can analogously be viewed as the life-blood of a business and hence the accounting bases, concepts and principles adopted ought to capture and report all the relevant accounting information to ensure reliability in its measurement. Reported profits reflect changes in wealth of owners and this can explain why major economic decisions in business are centered on financial performance as measured by profitability, (Cooley, 1983). It has been recognized that appropriate accounting information is important for successful management of any business entity, whether large or small (European Commission, 2008), 2008). It is crucial therefore that the accounting practices of SMEs supply complete and relevant financial information needed to improve economic decisions made by entrepreneurs. This research therefore focuses on investigating the types of accounting records being kept and maintained by SMEs, their completeness and the availability of accounting skills and knowledge to capture and process accounting information which can be used to measure performance in SMEs.
The study is aimed at achieving the following objectives:

1. To investigate the kinds of accounting record being kept and maintained by SMEs.

2. To investigate the extent to which accounting information is being used in measuring financial performance by SMEs.

3. To analyze the completeness of accounting records being kept by SMEs as a source of information for economic decision making.

4. To assess the need for specific regulation of accounting and financial reporting practices of SMEs.

\section{Literature Review}

Accounting for income and expenditure is the first essential step of accounting which is a system to provide a source of information to owners and all other interested parties. The importance of financial performance measurement to any business entity cannot be overemphasized. In this sense, the accounting bases, concepts and principles adopted ought to capture and report all the relevant accounting information to ensure reliability in its measurement. (Cooley (1983) emphasized that reported profits reflect changes in wealth of business owners.

(Maseko (2011) stipulate that Micro and Small business recordkeeping is the backbone of one's business. Keeping accurate accounting records is actually creates a profitable business. (Germain, 2010) finds that most business operators especially those in SME's perceive record keeping as a method of recovering initial investment in the form of cash at the end of the accounting period. If SME' are not maintained proper accounting records long term sustainability of the business is under question.

(Howard, 2009) emphasized that many small businesses failed to keep adequate records. This leads to major problems and quite possibly the closing of the business. Evidence shows that keeping good records helps to increase the chances of business survival. In essence, the SME's owners or manager should be personally involved in record keeping (Sian, 2006). Proper record keeping ensures long term sustainability of the business and anticipates long term prospects.

(Ismail, 2005) concluded that the development of a sound accounting information in SME's depends on the owners' level of accounting knowledge. Research has shown that majority of the SME's owners do not have the adequate accounting knowledge and therefore a few capable owners use professional firms to account for their business (Keasy, 1990); (Bohman, 1984). However, argue that the high cost of hiring professional accountants leaves the SME's owner or managers with no option but to outsource accounting information management. (Wichman, 1983) finds that accounting and marketing pose major challenges to management of SMEs and recommends that managers or owners in SME's must learn about record keeping and accounting. Perhaps cash flow is one of the major records in any enterprise. (Germain, 2010) asserts that small businesses must consider maintaining a positive 
cash flow as one of the important elements. By taking into consideration reviewed literature it is important to what extent do the owners and managers of SME' in Sri Lanka accounting records of their businesses.

\section{Methodology}

The researchers used the survey method. According to Cooper and Schindler, (2003), the survey method is a factfinding study that involves adequate and accurate interpretation of findings. The study was carried out by gathering data from primary sources in order to achieve the research objectives. The target population comprised of 100 registered SMEs in Gampaha District in Sri Lanka. Based on the research objectives, a survey questionnaire was developed.

The questionnaire was divided into three sections: profile of the business, accounting practices and perceptions about accounting practices. The questionnaire was pre-tested using 6 owner managers of retail shops, 4 owner-managers of manufacturing entities and 3 businesses of other services. A total of 150 questionnaires were distributed through networks of friends and colleagues to retail shops (selling groceries, clothing, hardware, pharmaceuticals), manufacturing entities (including building contractors, textiles, bakeries and other food processors) and a variety of other service providers (including hairdressers, law firms, insurance agents, business consultants and those offering secretarial services). A total of 115 of the distributed questionnaires were returned and of these 100 were accepted as complete for the purpose of data analysis. With relevant to collected data, analysis was then conducted based on the research objectives.

\section{Results}

Survey results are presented in this section. Table 1 shows that the majority of the business belongs to SMEs and that most of the SMEs are in the retail sector operating shops. $38 \%$ of the entities are medium sized businesses. Table 2 shows that the largest number of SMEs (74\%) is family businesses, followed by sole traders (15\%) and partnerships (10\%) respectively, with limited company comprising the smallest number $(1 \%)$ of SME businesses.

Table 1. Size of entity.

\begin{tabular}{lllll}
\hline Industrial Sector & \multicolumn{4}{l}{ Annual Revenue Base } \\
\hline & Micro & Small & Medium & Total \\
\hline Retail (shops) & 3 & 25 & 17 & 45 \\
Manufacturing & 1 & 10 & 10 & 21 \\
other services & 2 & 21 & 8 & 31 \\
Other & 0 & 0 & 3 & 3 \\
Total & 6 & 56 & 38 & 100 \\
Percentage (\%) frequency & 6 & 56 & 38 & 100 \\
\hline
\end{tabular}

Source: Authors' survey 2015

Table 2. Legal ownership of SMEs.

\begin{tabular}{lllll}
\hline Industrial Sector & & & & \\
\hline & Family business & Sole proprietor & partnership & Limited company \\
\hline Retail (shops) & 37 & 5 & 3 & 0 \\
Manufacturing & 12 & 5 & 3 & 1 \\
other services & 23 & 4 & 3 & 0 \\
Other & 2 & 1 & 1 & 0 \\
Total & 74 & 15 & 10 & 1 \\
Percentage (\%) frequency & & & & 31 \\
\hline
\end{tabular}

Source: Authors'survey 2015

\subsection{Respondent's Perceptions of Preparing Financial Statements}

Table 3 shows that owner-managers were preparers of accounts and financial statements, 12 used hired consultants to prepare financial statements and only 26 employed full-time accounting officers.

Table 3. Preparers of accounts and financial statements.

\begin{tabular}{lllll}
\hline Industrial Sector & & & & \\
\hline & Full time accounting officer & consultant & Owner manager & Total \\
\hline Retail (shops) & 14 & 3 & 28 & 45 \\
Manufacturing & 07 & 4 & 10 & 21 \\
services & 04 & 5 & 22 & 31 \\
Other & 01 & 0 & 02 & 03 \\
Total & 26 & 12 & 62 & 100 \\
Percentage (\%) frequency & 26 & 12 & 62 & 100 \\
\hline
\end{tabular}

Source: Authors' survey 2015

Respondents were asked to choose accounting records they kept in SMEs from a given list. Table 4 shows that the complete set of accounting records ranked highest with $42 \%$ and the cash book only book ranked second with $29 \%$. The primary entry books only ranked third with $5 \%$. It is important to mention that $29 \%$ respondents keep none for accounting records. $20 \%$ of the retail shops business kept complete set of accounting records and most of the SMEs in the service sector kept cash book only. 
Table 4. Accounting records kept by SMEs.

\begin{tabular}{llllll}
\hline Industrial Sector & Cash book only & Primary entry books only & Complete set of accounting records & None & Total \\
\hline Retail (shops) & 12 & 2 & 20 & 11 & 45 \\
Manufacturing & 07 & 1 & 9 & 04 & 21 \\
services & 2 & 0 & 02 & 05 & 31 \\
other & 0 & 05 & 42 & 01 & 3 \\
Total & 29 & 05 & 42 & 29 & 100 \\
Percentage (\%) frequency & 29 & & 29 & 100 \\
\hline
\end{tabular}

Source: Authors' survey 2015

\subsection{Use of ICT for Keeping Accounting Records}

Over and above accounting records kept, respondents were also asked how to keep accounting record. $73 \%$ of the respondents don't use IT for keeping accounting records. Majorities (44\%) of the respondents keep manual records and 29\% don't keep any of the records.

Table 5. Usage of ICT for keeping accounting records.

\begin{tabular}{|c|c|c|c|c|c|}
\hline \multicolumn{6}{|l|}{ Industrial Sector } \\
\hline & Manual & Excel & Accounting package & No any records & Total \\
\hline Retail (shops) & 24 & 6 & 4 & 11 & 45 \\
\hline Manufacturing & 10 & 5 & 2 & 04 & 21 \\
\hline services & 08 & 4 & 5 & 14 & 31 \\
\hline Other & 02 & 0 & 1 & 0 & 03 \\
\hline Total & 44 & 15 & 12 & 29 & 100 \\
\hline Percentage $(\%)$ frequency & & & & & \\
\hline
\end{tabular}

Source: Authors' survey 2015

\subsection{Respondents' Perceptions About Reasons for Calculating Profit}

Table 6 shows that $26 \%$ of the SMEs did not calculate profit while only $22 \%$ respondents to have calculated profit. Also, $21 \%$ of the SMEs indicated that they calculated profit for tax purposes, $04 \%$ for profit sharing reasons, $48 \%$ for decision making while $26 \%$ gave other reasons for calculating profit. For the purpose of this research, only decision making is considered for performance measurement.

Table 6. Reasons for calculating profit.

\begin{tabular}{llllll}
\hline Industrial Sector & & & & \\
\hline & Tax purpose & Profit sharing & Decision taking & None & Total \\
\hline Retail (shops) & 12 & 3 & 20 & 10 & 45 \\
Manufacturing & 02 & 0 & 14 & 08 & 21 \\
services & 05 & 1 & 14 & 11 & 31 \\
Other & 02 & 0 & 01 & 0 & 3 \\
Total & 21 & 4 & 49 & & 100 \\
Percentage (\%) frequency & & & & \\
\hline
\end{tabular}

Source: Authors' survey 2015

\subsection{Challenges Faced in Keeping Proper Accounting Records}

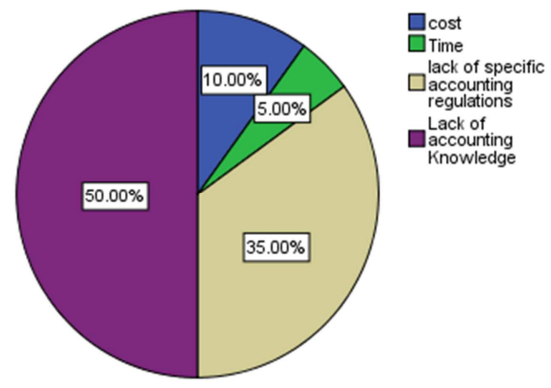

Source: Authors' survey 2015

Figure 2. Challenges faced by SMEs.
Figure 2 shows that the majority of SMEs (50\%) attributed the challenges they faced in keeping proper accounting records to lack of accounting knowledge, 15\%of SMEs indicated cost and time constraints as challenges while $35 \%$ cited lack of specific accounting regulations for SMEs as contributing to challenges they faced in keeping proper accounting records.

\subsection{Respondents'Suggestions Given to Improve Accounting Practices of SMEs}

Table 7 shows that most of the SMEs (38\%) suggested Accounting training programme from universities or accounting bodies as a way to improve their accounting practices. $29 \%$ of the SMEs suggested they need book 
keeping training. $16 \%$ would hire consultants to improve their accounting practices. $17 \%$ gave other suggestions.

Table 7. Suggestions to Improve Accounting Practices of SMEs.

\begin{tabular}{ll}
\hline Suggestions & $\%$ \\
\hline & 29 \\
Book keeping Training & \\
Accounting-Training programmes conducted by Universities. Professional accounting Bodies & 38 \\
Hire consultant/book keeper & 16 \\
Other & 17 \\
Total & 100 \\
\hline
\end{tabular}

Source: Authors' survey 2015

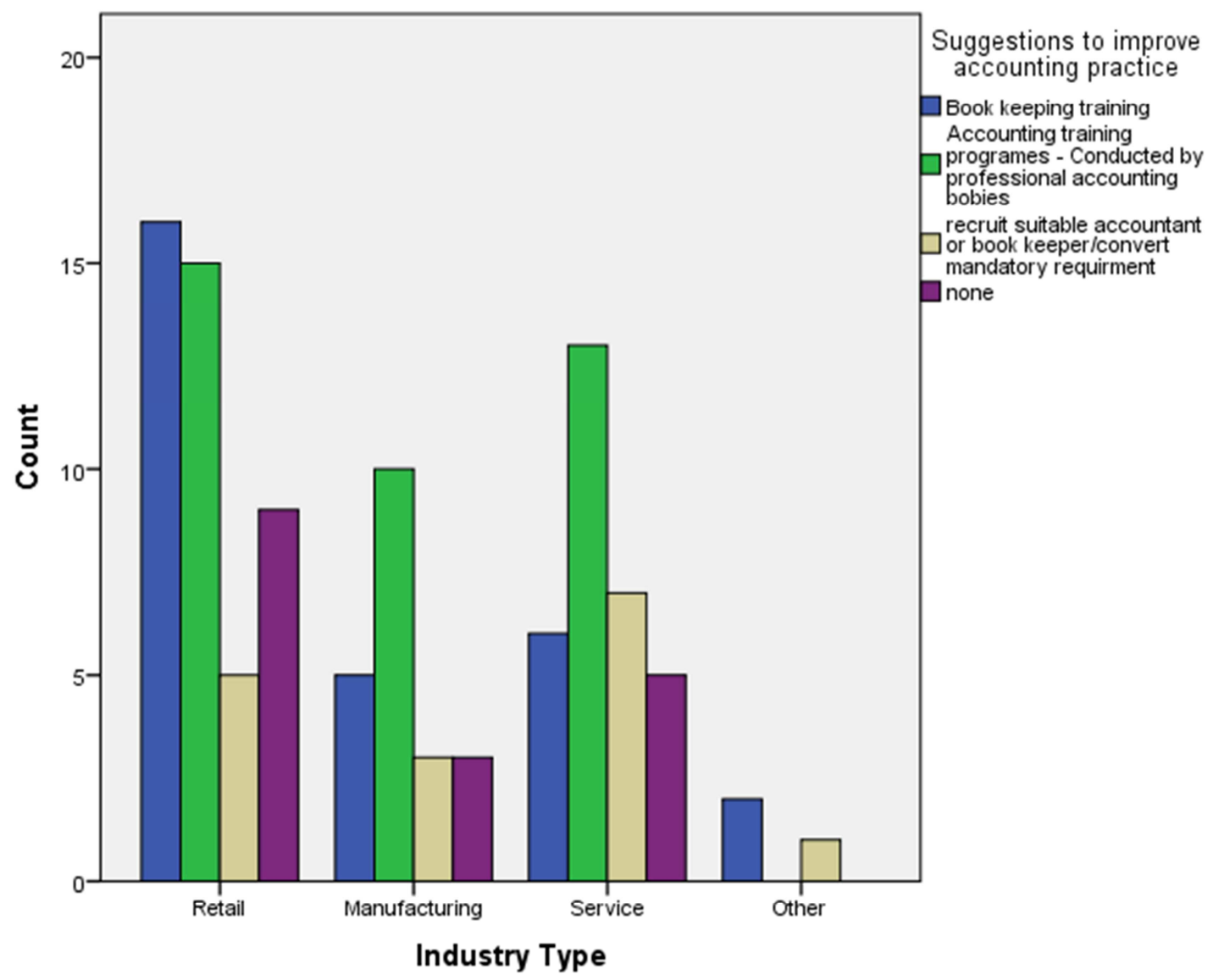

Source: Authors' survey 2015

Figure 3. Suggestion given by Industry type.

Figure 3 shows suggestions given by the SME's belong to retail, manufacturing, service and other sectors. Accordingly all sectors emphasized the need of book keeping/accounting training by the professional accounting bodies and to recruit suitable accounting officer for the purpose.

\section{Discussion}

The results confirm that SMEs do keep complete set of accounts, especially to capture sales and cost of sales. There is however a few number of SMEs are keeping primary entries to record information. SMEs in the retail shops business are keeping complete set of accounts for controlling inventory and those in the service sector keeps cash book only as owners try to maintain their cash. Record keeping using ICT in SMEs is therefore not being done for the purpose of capturing accounting information for performance measurement but few SMEs use ICT for accounting information using ICT for security and control. This is supported by only $27 \%$ of SMEs preparing financial statements using ICT to report financial performance.

The results also confirm that the findings of (McMahon, 1999) that most SMEs do not prepare a complete set of financial statements with some $(29 \%)$ not preparing any financial statement at all. An entity may fail to prepare financial statements even with well-maintained books of accounts because the preparation of financial statements requires accounting knowledge/skills and this, as revealed by 
the results, is lacking in $85 \%$ of SMEs. As the business grows, the need to prepare complete set of financial statements increases, especially into medium size. It is at the medium size that the business financial performance reporting will open not only to internal users but also to external users like lenders. Results further shows that ownermanagers dominate preparers of financial statements in SMEs. (Wichman, 1983) showed that most of the ownermanagers are not financially literate and they may be resorting to this practice to avoid the cost of hiring accountants. Confirming the findings of (Wichman, 1983), the results shows that majority of the respondents suggest they need a proper training about accounting records. This means that, in the statutory requirements to prepare financial statements is needed for the chief users. Owner-managers in SMEs value the use of profitability in measuring performance.

\section{Conclusion and Recommendations}

The study revealed that majority of SMEs do not maintain proper accounting records because of lack of accounting knowledge and lack of specific accounting regulations. As a result, use of accounting information is insufficient to support financial performance. This study reveals that Universities and Accounting institutions should organize training programmes and provide some SME-specific accounting guidelines and provide template forms for capturing accounting information. The academic institutions and other bodies which are responsible for SMEs should initiate accounting training programmes for small and medium scale businesses. Further, this study recommends that record keeping in SMEs must be made mandatory to improve their accounting practices and increase chances of them formalizing their business operations.

\section{References}

[1] Bohman, H., \& Boter, H. (1984). Planning in small and medium sized firms - The challenges and premises of the strategic planning: Department of Business Administration and Economics, Umea University Sweden.

[2] Cooley, P. L., \& Charles, E. Edwards. (1983). Financial Objectives of Small Firms. American Journal of Small Business, 8 (1), 27-31.

[3] Cooper, D. R., \& Schindler, P. S. (2003). Business Research Methods (8th edition). USA: McGraw-Hill.

[4] Cooper, D. R., \& Schindler, P. S. (2006). Business Research Methods (9th edition). USA: McGraw-Hill.

[5] auda, A., \& Azeko, I. (2015). An Assessment of Financial
Records Keeping Behaviour of Small Scale Businesses in Ghana: A Case Study of Bolgatanga Municipality, International Journal of Finance and Accounting, 4 (3), 187-194.

[6] European Commission, E. (2008). Enterprise and Industry Directorate-General: Find Report of the Expert Group: Accounting system for small enterprises - Recommendations and good practices.

[7] Germain, P. J. (2010). Top 10 Small business book keeping Tips. from http://ezinearticles.com

[8] Howard, P. (2009). Good Recording Important for Sucessful Business: Angelo State University.

[9] Ismail, N. A., \& KIng, M. (2005). Firm performance and AIS alignment in Malaysian SMEs. International Journal of Accounting Information systems, 6 (4), 241-259.

[10] Keasy, K., \& Short, H. (1990). The Accounting Burdens facings small firms: an emprirical research note. Journal of Accounting Business Research, 20 (80), 307-313.

[11] Maseko, N., \& Manyani, O. (2011). Accounting Practices of SMEs in Zimbabwe: An Investigative study of record keeping for performance measurements - a case study of Bindura. Journal of Account and Tax, 3 (8), 171-180.

[12] McMahon, R. G. P. (1999). Putting SME financial reporting into Theoritical and Practical perspective.. In R. p. s. 98-10 (Ed.). Flinder University South Australia, Adelaide.

[13] Moore WC, Petty JW, Palich CH, Longernecker JG., 2008. Managing small business: An entrepreneurial emphasis, $14^{\text {th }}$ ed.

[14] Ntim, A. L., Evans, O. Anthony, F. (2014). Accounting practices and control systems of small and medium size entities: A case study of Techiman municipility. Journal of Finance and Accounting. 2 (3), 30-40

[15] Tucker, D., \& Seluck, S. S.,. (2000). Which factors affec t entrepreneurial intentions of University Students? Journal of European Industrial Training, 33 (2), 142-159.

[16] Wichman, H. (1983). Accounting and Marketing - Key small business problems. Journal of Small Business, 7 (4), 19-26.

[17] Wichman H (1983). Accounting and marketing - key small business problems Journal of Small Businesses. Volume 7 (4): 19-26.38.

[18] Yousef, A. S. (2013) The use of accounting information by Small and Medium Enterprises: A Case study of South district of Jordan: Journal of Finance and Accounting, Volume 4 (6) 2222-2847.

[19] Zhou L., (2010). The Research on Issues and Countermeasures of Accounting Information of SMEs. International Journal of Business Management, Volume 5 (3): 223-225.

[20] Zindiye S, Roberts-Lombard M, Herbst G., 2008. An empirical investigation into the factors affecting the performance of SMEs in the manufacturing sector of Harare, Zimbabwe. Fort Hare University. 